Justyna Grochowska*

ORCID: 0000-0001-8139-1899

Uniwersytet Wrocławski

https://doi.org/10.19195/1733-5779.30.8

\title{
Gwarancyjność i spójność regulacji dotyczących przeszukania osoby, kontroli osobistej oraz sprawdzenia prewencyjnego
}

\section{JEL Classification: K400}

Słowa kluczowe: przeszukanie, kontrola osobista, konstytucja, prywatność, postępowanie karne

Keywords: search, personal control, right to privacy

\begin{abstract}
Abstrakt: Opracowanie jest analizą regulacji przeszukania i kontroli osobistej wraz z próbą ustalenia ich poziomu gwarancyjności oraz spójności. Analizie poddano również instytucję sprawdzenia prewencyjnego jako czynności zbliżonej w swoim charakterze do kontroli osobistej, co ma na celu całościowe poruszenie zagadnienia związanego z szeroko rozumianą ingerencją w prawo do prywatności ze względu na konieczność ochrony porządku i bezpieczeństwa publicznego. Celem artykułu jest próba znalezienia optymalnego rozwiązania pozwalającego ograniczyć nadużycia w zakresie stosowania tych instytucji. Ponadto artykuł poddaje ocenie aktualną regulację tych instytucji oraz zakreśla granice ich stosowania, po to by zapewnić wystarczające gwarancje osobom dotkniętym negatywnymi skutkami wskazanych czynności.
\end{abstract}

\section{Legal safeguards and consistency of regulations related to search of person, personal control and preventive check}

\begin{abstract}
The article provides an analysis of search and personal control regulations along with an attempt to determine their level of guarantee and consistency. The institution of preventive checking was also analyzed as similar in nature to personal control. The paper aims at comprehensively addressing the issue of broadly understood interference with the right to privacy motivated by the need to protect public order and security. The author attempts to find the optimal regulation which guarantees the reduction of abuse of powers vested in the investigating authorities. In addition, the article assesses the current regulation of the above-mentioned institutions and outlines the limits of their application in order to provide sufficient guarantees for persons affected by them.
\end{abstract}

* Opiekun naukowy (Scientific Tutor) — Wojciech Jasiński 
Przedmiotem artykułu jest omówienie poziomu gwarancyjności instytucji przeszukania (art. $219 \S 1$ i 2 k.p.k. ${ }^{1}$ ) i kontroli osobistej (art. 15 ust. 1 pkt 5 ustawa o Policji ${ }^{2}$ ), a także spójności tych regulacji, co ma szczególne znaczenie ze względu na ich daleko idące podobieństwo. Dodatkowo analizie poddano instytucję sprawdzenia prewencyjnego, która w swoim charakterze zbliżona jest do kontroli osobistej. Celem niniejszego opracowania jest ukazanie kontrowersji wynikających $\mathrm{z}$ istnienia $\mathrm{w}$ polskim prawie podobnych do siebie pod wieloma aspektami instytucji mających niebagatelne znaczenie dla poddanej tym czynnościom jednostki i jej przyrodzonych praw.

Mając na uwadze, iż wspomniane czynności charakteryzują się daleko idącą ingerencją w prawa i wolności osobiste jednostki, należy podkreślić gwarancyjne znaczenie ich regulacji prawnej. W wypadku wskazanych instytucji niewątpliwie istotne jest, aby stosowne unormowania prawa wskazywały przesłanki, tryb i formę, sposób utrwalania przebiegu omawianych czynności oraz zapewniały poszanowanie prawa jednostki do sądu. To zapewnia bowiem odpowiedni poziom gwarancji chroniący jednostkę przed bezprawną (podjętą bez podstawy prawnej lub poza granicami prawa) działalnością organów procesowych ${ }^{3}$. Organy dokonujące przeszukania czy też kontroli osobistej albo sprawdzenia prewencyjnego muszą więc pamiętać zarówno o normach sensu stricto gwarancyjnych, jak i o normach, które dają szansę jednostce na korektę błędnych ustaleń faktycznych na przykład o pouczeniu o możliwości złożenia środka zaskarżenia ${ }^{4}$.

$\mathrm{Na}$ wstępie należy wspomnieć, że regulacje dotyczące przeszukania oraz kontroli osobistej zostały w znaczący sposób przemodelowane wskutek wydanego przez Trybunał Konstytucyjny (dalej: TK) wyroku o sygn. akt K 17/145, w którym przyjęto, że art. $219 \S 2$ k.p.k. w zakresie, w jakim przewiduje przeszukanie osoby, nie określając jego granic, jest niezgodny z art. 41 ust. $1 \mathrm{i}$ art. $47 \mathrm{w}$ zw. $z$ art. 31 ust. 3 Konstytucji ${ }^{6}$. Podobnie TK uznał w odniesieniu do kontroli osobistej, stwierdzając niezgodność art. 15 ust. 7 ustawy o Policji z art. 45 ust. 1 i art. 77 ust. 2 Konstytucji ${ }^{7}$ w zakresie, w jakim nie przewidziano sądowej kontroli zgodności z prawem dokonywanej kontroli osobistej. We wskazanym orzeczeniu TK podniósł, że przeszukanie osoby i kontrola osobista muszą być precyzyjnie unor-

${ }^{1}$ Ustawa z dnia 6 czerwca 1997 roku Kodeks postępowania karnego (tekst jedn. Dz.U. z 2018 r. poz. 1987 z późn. zm.).

${ }^{2}$ Ustawa z dnia 6 kwietnia 1990 roku o Policji (tekst jedn. Dz.U. z 2019 r. poz. 161 z późn. zm.).

3 J. Skorupka, [w:] System Prawa Karnego Procesowego. Zagadnienia ogólne, t. 1, cz. 1, red. P. Hofmański, Warszawa 2013, s. 195-196. Uwagę powyższą należy analogicznie odnieść do organów realizujących czynności zbliżone do czynności procesowych, odpowiadające tym pierwszym swoim charakterem.

4 S. Waltoś, P. Hofmański, Proces karny. Zarys systemu, Warszawa 2018, s. 350.

5 Wyrok TK z dnia 14 grudnia 2017 roku, K 17/14, OTK-A 2018/4.

${ }^{6}$ Konstytucja Rzeczypospolitej Polskiej z dnia 2 kwietnia 1997 roku (Dz.U. Nr 78, poz. 483 z późn. zm.).

7 Ibidem. 
mowane w ustawie ze względu na to, że stanowią ograniczenie konstytucyjnych praw i wolności. Dodatkowo Trybunał zauważył, że

optymalizacja regulacji ustawowej powinna w rezultacie pozwolić jednostce na jednoznaczne ustalenie, kto, w jakich okolicznościach, na jakiej podstawie i w jakim zakresie, jest uprawniony naruszać jej nietykalność osobistą. Dodatkowym elementem przeciwdziałającym arbitralności władzy i dowolnemu wyznaczaniu granic wolności osobistej jest powierzenie władzy sądowniczej kompetencji w zakresie oceny legalności podejmowanych czynności ${ }^{8}$.

Trybunał zwrócił również uwagę na trudności w rozróżnieniu instytucji przeszukania od kontroli osobistej. Skutkiem wydanego orzeczenia były zmiany normatywne wprowadzające kompleksowe unormowanie instytucji kontroli osobistej na poziomie ustawowym, zawierające zarówno wskazanie przesłanek, jak i obszerną regulację sposobu jej przeprowadzenia. W wypadku przeszukania nie zdecydowano się na doprecyzowanie istniejących przepisów, poprzestając na modyfikacji ogólnej dyrektywy z art. 227 k.p.k.

W toku analizy problematyki gwarancyjności oraz spójności instytucji przeszukania oraz kontroli osobistej i sprawdzenia prewencyjnego skupiono się na przeszukaniu osoby oraz jej odzieży i podręcznych przedmiotów. To bowiem w tym zakresie ujawnia się główna odnośnie do niniejszego opracowania problematyka spójności regulacji przeszukania oraz kontroli osobistej i sprawdzenia prewencyjnego. Warto także podkreślić szczególną dolegliwość przeszukania osoby (analogicznie kontroli osobistej i sprawdzenia prewencyjnego), która może wiązać się nawet $\mathrm{z}$ ingerencją $\mathrm{w}$ sferę intymną jednostki. W artykule ograniczono się także do analizy kontroli osobistej uregulowanej w ustawie o Policji. Pominięto analizę innych ustaw, w których przewidziana została kontrola osobista, na przykład ustawa o ABW oraz AW (art. 23 ust. 1 pkt 5) ${ }^{9}$, o Straży Granicznej (art. 11 ust. 1 pkt 2$)^{10}$ czy ustawa o CBA (art.14 ust. 1 pkt 5) ${ }^{11}$. Analogicznie postąpiono w wypadku sprawdzenia prewencyjnego. Ze względu jednak na daleko idącą zbieżność wskazanych instytucji sformułowane wnioski należy odnieść odpowiednio do kontroli osobistej i sprawdzenia prewencyjnego dokonywanych przez inne niż Policja organy.

Przeszukanie nie ma definicji legalnej, która jednoznacznie określałaby dopuszczalne granice jego zastosowania. W celu głębszego — aniżeli tylko wykładnia unormowań kodeksowych — zrozumienia, czym owa instytucja jest, należy sięgnąć do dorobku doktryny w tym przedmiocie. M. Cieślak definiuje przeszu-

8 Wyrok TK z dnia 14 grudnia 2017 roku, K 17/14, OTK-A 2018/4.

9 Ustawa z dnia 24 maja 2002 roku o Agencji Bezpieczeństwa Wewnętrznego oraz Agencji Wywiadu (tekst jedn. Dz.U. z 2018 r. poz. 2387 z późn. zm.).

${ }^{10}$ Ustawa z dnia 12 października 1990 roku o Straży Granicznej (tekst jedn. Dz.U. z 2019 r. poz. 147 z późn. zm.).

11 Ustawa z dnia 9 czerwca 2006 roku o Centralnym Biurze Antykorupcyjnym (tekst jedn. Dz.U. z 2019 r. poz. 1921). 
kanie jako „przymusowy sposób poszukiwania osób lub rzeczy dla celów procesu karnego"12. Przymusowy charakter omawianej czynności podkreślają również L. Hochberg, A. Murzynowski i L. Schaff, definiując przeszukanie jako „czynność procesową (o charakterze przymusowym) organów ścigania, zmierzającą do: a) ujęcia podejrzanego, b) wykrycia dowodów, c) wykrycia przedmiotów uzyskanych za pomocą przestępstwa lub podlegających konfiskacie"13. Natomiast W. Grzeszczyk twierdzi, że przeszukanie jest czynnością dowodową zmierzającą do odnalezienia osoby podejrzanej lub rzeczy, która stanowi dozwoloną przez ustawę ingerencję w dobra podlegające ochronie konstytucyjnej — prawo do nietykalności osobistej (art. 41 ust. 1 Konstytucji RP) i prawo do nienaruszalności mieszkania (art. 50 Konstytucji RP) ${ }^{14}$. Najlepiej oddającą charakter prawny przeszukania definicją jest jednak definicja stworzona przez Z. Uniszewskiego, który stwierdził, że „przeszukanie jest to określona przez Kodeks postępowania karnego czynność kryminalistyczna o charakterze dochodzeniowo-śledczym, z reguły nastawiona na znalezienie i zabranie przedmiotów, zwierząt lub osób"15. Słusznie został podkreślony w tej definicji kryminalistyczny charakter omawianej czynności. Należy bowiem zauważyć, że o ile w k.p.k. wskazany jest między innymi cel i ramy dopuszczalności przeszukania, o tyle sam sposób jego przeprowadzenia nie został uregulowany. Przebieg tej czynności jest zatem determinowany wskazaniami kryminalistyki i wypracowanej przez nią taktyki. Skupiając się na omówieniu gwarancyjności przeszukania, należy wyjść od jego regulacji ustawowej. W wypadku przeszukania osoby (jej odzieży i podręcznych przedmiotów) przepis art. 219 § 2 k.p.k. określa granice tej czynności, odwołując się do celu w postaci potrzeby znalezienia jedynie rzeczy mogących stanowić dowód w sprawie bądź podlegających zajęciu w postępowaniu karnym. Ponadto musi występować przesłanka uzasadnionej podstawy do przypuszczenia, że wymienione rzeczy znajdują się w określonym miejscu. Należy przez to rozumieć, że przeszukania dokonuje się wtedy, gdy istnieją wiarygodne dane, które pozwalają przypuszczać, że dana rzecz znajduje się u danej osoby lub przy tej osobie ${ }^{16}$. Z art. $219 \S 1$ k.p.k. wynika bowiem, że tylko na podstawie ,uzasadnionych podstaw”, to znaczy na podstawie informacji wynikających zarówno z dowodów ścisłych, jak i swobodnych, można spodziewać się, że poszukiwana rzecz znajduje się przy danej osobie ${ }^{17}$. Wynika z tego, że organ, chcąc znaleźć przedmiot, może przeszukać zarówno odzież oso-

12 M. Cieślak, Zagadnienia dowodowe w procesie karnym, Warszawa 1955, s. 303.

13 L. Hochberg, A. Murzynowski, L. Schaff, Komentarz do kodeksu postępowania karnego, Warszawa 1959, s. 162.

14 W. Grzeszczyk, Komentarz do art. 219, teza 1-2, [w:] Kodeks postępowania karnego. Komentarz, Warszawa 2012.

15 Z. Uniszewski, Przeszukanie problematyka kryminalistyczna, Warszawa 2000, s. 44.

16 T. Grzegorczyk, Kodeks postępowania karnego. Komentarz do art. 1-467, t. 1, Warszawa 2014, s. 790.

17 Ibidem. 
by, jak i jej podręczne przedmioty. Przeszukanie osoby powinna przeprowadzić w miarę możliwości osoba tej samej płci. Podmiotami uprawnionymi do przeprowadzenia przeszukania są zgodnie z art. $220 \S 1$ k.p.k. prokurator albo na polecenie sądu lub prokuratora także Policja, a w wypadkach wskazanych w ustawie także inny organ. Za inne organy uznaje się te wskazane w dyspozycji art. 312 k.p.k., czyli organy Straży Granicznej, ABW, Krajowej Administracji Skarbowej, CBA, Żandarmerii Wojskowej. Ponadto ustawa karnoprocesowa przyznaje uprawnienie do przeprowadzenia tej czynności organom przewidzianym w przepisach szczególnych. Są to organy podatkowe, Straż Parku, Państwowa Straż Łowiecka, Straż Leśna, Państwowa Straż Rybacka ${ }^{18}$. Przyjmuje się, że co do zasady organem uprawnionym do zarządzenia przeszukania jest sąd ${ }^{19}$, ale gdy mowa o postępowaniu przygotowawczym to prokurator jako dominus litis jest osobą decyzyjną, co uznaje się za rozwiązanie pragmatyczne ${ }^{20}$. Zarządzenie przeszukania przybiera formę postanowienia. $Z$ dokonanej czynności należy sporządzić protokół.

Przepis art. $220 \S 3$ k.p.k. przewiduje możliwość przeprowadzenia przeszukania w sytuacjach niecierpiących zwłoki. Chodzi o zaistnienie sytuacji, w której odłożenie przeszukania w czasie, spowodowane oczekiwaniem na postanowienie sądu lub prokuratora, mogłoby przyczynić się do utraty lub zniekształcenia dowodów. Aby tego uniknąć, Policja lub inny organ okazują w takim wypadku osobie przeszukiwanej nakaz kierownika swojej jednostki lub legitymację służbową, po czym mają obowiązek niezwłocznie uzyskać zatwierdzenie przeszukania przez sąd lub prokuratora. Istotną gwarancją $\mathrm{w}$ wypadku przeprowadzenia tego rodzaju przeszukania jest konieczność pouczenia przez organ osoby poddanej przeszukaniu o prawie zgłoszenia żądania doręczenia takiego zatwierdzenia. Organ obowiązany jest niezwłoczne zwrócić się do sądu albo prokuratora celem zatwierdzenia przeszukania oraz doręczyć postanowienie o zatwierdzeniu w terminie 7 dni od daty czynności osobie, która zgłosiła do protokołu takowe żądanie.

Kontrola osobista jest czynnością administracyjno-porządkową uregulowaną w ustawie z dnia 6 kwietnia 1990 roku o Policji. Jak wspomniałam, jest to

18 A. Opalska-Kasprzak, Przeszukanie. Problematyka prawna i kryminalistyczna, Warszawa 2018, s. 77.

19 W tym miejscu należy mieć na względzie art. 235 k.p.k., zgodnie z którym oprócz sądu również referendarz sądowy dokonuje czynności przewidzianych w rozdziale 25 k.p.k. Są to jednak wyłącznie czynności wymienione w art. 231 § 1 k.p.k., 232 § 1 k.p.k. oraz 232 a $~ 2$ k.p.k. (K. Dąbkiewicz, Komentarz do art. 235, [w:] idem, Kodeks postępowania karnego. Komentarz do zmian 2015, Warszawa 2015). Z uwagi na wąski zakres czynności, które nie stanowią wymiaru sprawiedliwości, przekazanie tych uprawnień referendarzowi sądowemu należy ocenić pozytywnie przede wszystkim ze względu na zmniejszenie zaangażowania sędziów w sprawach prostszych merytorycznie, co przekłada się na przyspieszenie postępowania (M. Kurowski, Komentarz do art. 93 a k.p.k., teza 1, [w:] Kodeks postępowania karnego. Komentarz, t. 1, red. D. Świecki, Warszawa 2018).

20 R.A. Stefański, [w:] Kodeks postępowania karnego. Komentarz, t. 2, red. R.A. Stefański, S. Zabłocki, Warszawa 2019, s. 717-718. 
czynność bardzo zbliżona do czynności przeszukania. Bywa zresztą uznawana za jego uproszczoną formę ${ }^{21}$. Kontrola osobista jako czynność administracyjno-porządkowa jest dokonywana poza procesem karnym, po to by zabezpieczyć lub ujawnić dowody czy też rzeczy mające związek z realizacją czynu zabronionego ${ }^{22}$. Kontrola osobista ma swoją podstawę w art. 15 ust. 1 pkt 5 ustawy o Policji, który wskazuje możliwość jej dokonania w razie istnienia uzasadnionego podejrzenia popełnienia czynu zabronionego pod groźbą kary bądź w celu znalezienia wymienionych w tej ustawie przedmiotów, takich jak broń, przedmioty niebezpieczne lub takie, których posiadanie jest zabronione oraz przedmioty podlegające przepadkowi. Gdy mowa o uzasadnionym podejrzeniu popełnienia czynu zabronionego, uznaje się, że sama groźba naruszenia porządku publicznego nie wystarczy i kontrola osobista powinna być dokonywana wówczas, gdy uzasadnione jest wszczęcie postępowania przygotowawczego ${ }^{23}$. Przepis art. $15 \mathrm{~d}$ ustawy o Policji przewiduje katalog wskazujący, co dokładnie może podlegać sprawdzeniu. Chodzi między innymi o zawartość odzieży i obuwia oraz innych przedmiotów znajdujących się na ciele bez odsłaniania przykrytej odzieżą powierzchni ciała, chyba że odsłonięcie ciała będzie konsekwencją ujawnienia broni lub przedmiotów, o których mowa w art. 15 ust. 1 pkt 5 ustawy o Policji, a ich odebranie jest niezbędne. Ponadto policjant może sprawdzić jamę ustną, nos, uszy oraz włosy. Co więcej może on w szczególne uzasadnionych wypadkach dokonać sprawdzenia miejsc intymnych. Ustawa nie wskazuje, czym powinien kierować się policjant, uznając ów przypadek za „szczególnie uzasadniony”. Ustawodawca pozostawia Policji w tej kwestii swobodę decyzyjną.

W celu pełnego omówienia problemu związanego $\mathrm{z}$ istnieniem $\mathrm{w}$ polskim prawie instytucji podobnych do przeszukania należy wskazać regulację instytucji przewidzianej przez ustawę o Policji, która ma podobny cel i charakter jak kontrola osobista. Chodzi o sprawdzenie prewencyjne osoby, które uregulowano w art. 15 ust. 1 pkt 9 ustawy o Policji. Niewątpliwie jest to łagodniejszy od kontroli osobistej środek stosowany w celu zapobieżenia bezprawnym zamachom skutkującym zagrożeniem życia, zdrowia, mienia lub przed nieuprawnionymi działaniami skutkującymi zagrożeniem życia, zdrowia czy bezpieczeństwa i porządku publicznego. Polega na manualnym sprawdzeniu osoby, jej odzieży i innych przedmiotów znajdujących się na jej ciele lub przez nią posiadanych, a także na sprawdzeniu osoby — w zależności od okoliczności — za pomocą środków technicznych albo biochemicznych lub przy użyciu psa. Ponadto na przykład w stosunku do osoby zatrzymanej, konwojowanej lub doprowadzanej można żądać zdjęcia przez tę osobę odzieży, a nawet dokonać oględzin ciała. Niewątpliwie jest to istotna inge-

21 J. Karaźniewicz, Przeszukanie i czynności zbliżone do przeszukania w teorii i praktyce organów ścigania, [w:] Węzłowe problemy procesu karnego, red. P. Hofmański, Warszawa 2010, s. 287.

22 T. Grzegorczyk, op. cit., s. 791.

23 S. Waltoś, P. Hofmański, op. cit., s. 382. 
rencja w prywatność jednostki, jeżeli uwzględnić, że mówimy tutaj o czynności nastawionej na samo sprawdzenie osoby, a nie na ścisłą kontrolę jak w wypadku kontroli osobistej. Sprawdzenie prewencyjne najczęściej będzie w przypadku wpuszczania osób na teren ochraniany przez policję lub w związku z udziałem w imprezach masowych czy zgromadzeniach, po to by zapobiec zdarzeniom o charakterze terrorystycznym. Jednakże ustawodawca pozostawia organom Policji dużą dozę elastyczności co do podjęcia decyzji o przeprowadzeniu sprawdzenia prewencyjnego. Ma to związek z brakiem ograniczeń w stosowaniu tego środka. Ustawodawca nie wskazał sytuacji, w których dopuszcza się przeprowadzenie sprawdzenia prewencyjnego jedynie w wypadku dużego nagromadzenia się osób w związku z imprezą masową lub innymi podobnymi formami zgromadzeń bądź w związku z doprowadzaniem przez policję osoby do pomieszczenia w celu wytrzeźwienia. Co prawda w ustawie o Policji wymienia takie sytuacje, ale są one jedynie uzupełnieniem generalnej normy, która zezwala na dokonanie sprawdzenia prewencyjnego w zależności od sytuacji w celu ochrony: życia, zdrowia, mienia czy też porządku publicznego. Ponadto w wyniku dokonanego sprawdzenia prewencyjnego nie przysługują jednostce żadne formy kontroli prawidłowości dokonanej czynności, czyli w tym zakresie nie ma prawa do sądu.

Mając pełny obraz tego, jak kształtują się możliwości dokonania przeszukania oraz kontroli osobistej, a także sprawdzenia prewencyjnego, należy stwierdzić, że dwie pierwsze są do siebie bardzo podobne. Tym, co je różni, jest jednak cel, w jakim są dokonywane przez policję (inne uprawnione służby). W wypadku przeszukania jest to znalezienie rzeczy mogących być dowodem w sprawie lub podlegających zajęciu w postępowaniu karnym. Celem kontroli osobistej jest z kolei zabezpieczenie lub ujawnienie dowodów mających związek z czynem zabronionym lub przeprowadzenie kontroli wskutek istnienia uzasadnionego podejrzenia popełnienia czynu zabronionego pod groźbą kary, po to by zapewnić bezpieczeństwo i porządek publiczny.

Oceniając spójności regulacji w tej kwestii, widoczny jest fakt wprowadzenia do polskiego systemu prawa instytucji, które choć formalnie mają inny cel, to $\mathrm{w}$ praktyce $\mathrm{W}$ związku $\mathrm{z}$ ich licznymi podobieństwami mogą być stosowane zamiennie. Może to skutkować nieprawidłowościami. Ujawnia się to między innymi przy zatrzymaniu osoby i czynnościach z tym związanych. Chodzi tutaj w szczególności o przypadki, w których funkcjonariusze Policji w toku czynności pozaprocesowych, między innymi podczas kontroli osobistej, ujawnią przedmiot, którego posiadanie jest zabronione. W materiałach dydaktycznych skierowanych do Policji wskazuje się, że policjanci często mylnie twierdzą, iż w takim wypad$\mathrm{ku}$ automatycznie należy dokonać przeszukania ${ }^{24}$. Nie zawsze wiedzą bowiem, z jakiej instytucji w danym momencie należy skorzystać: czy należy dokonać

24 G. Babieracki, J. Konewko, S. Młynarski, Sprawdzenie osoby, kontrola osobista a przeszukanie w codziennej stużbie policjanta, Słupsk 2011, s. 17. 
przeszukania, czy też poprzestać na kontroli osobistej albo sprawdzeniu osoby ${ }^{25}$. Wskazuje to trudności w prawidłowym zastosowaniu tych podobnych do siebie czynności ${ }^{26}$. J. Karaźniewicz zwróciła także uwagę na nieprecyzyjność w sformułowaniu przepisów, co przekłada się na dowolność w uznaniu dokonanej czynności bądź za kontrolę osobistą, bądź za przeszukanie ${ }^{27}$. Jak zauważa, „,zęsto każde sprawdzenie rozpoczynane jest jako kontrola osobista, natomiast ostateczna kwalifikacja czynności dokonywana jest w zależności od jej wyników"28. Problem ten dostrzegł również Prokurator Generalny w stanowisku przedstawionym w sprawie K 17/14 ${ }^{29}$, wskazując, iż poszczególne służby wyposażono w uprawnienia, które nazwano inaczej, ale merytorycznie są one równoważne. Zatem podobne sformułowanie celów skutkuje wątpliwościami co do tego, czy ostatecznie zakwalifikować daną czynność jako kontrolę osobistą, czy przeszukanie. Cele tych instytucji są formalnie różne, ale mimo to nie odbiegają od siebie znacząco. Celem przeszukania jest znalezienie rzeczy mogących stanowić dowód w sprawie, podczas gdy w kontroli osobistej jest to zabezpieczenie lub ujawnienie rzeczy mających związek z czynem zabronionym. Tak więc istota obu instytucji sprowadza się do tego samego, czyli znalezienia i zabezpieczenia dowodów ${ }^{30}$. Kiedy bowiem przedmiot ma związek z czynem zabronionym, jednocześnie może on stanowić dowód w sprawie. $Z$ tego względu należy na poziomie legislacyjnym uregulować w odmienny sposób cele obu instytucji, tak aby rozróżnienie to było wyraźne i zrozumiałe dla organów procesowych, co pozwoli uniknąć nadużyć w tej kwestii.

Poddając analizie organ uprawniony do zarządzenia przeszukania osoby, należy zastanowić się, czy jest on odpowiedni z punktu widzenia skutecznej ochrony praw podmiotowych jednostki, a tym samym zapewnienia odpowiedniego poziomu gwarancyjności procesu karnego. Jak wskazano, takim organem jest prokurator w postępowaniu przygotowawczym oraz sąd na etapie postępowania jurysdykcyjnego. Przepis art. $220 \S 1$ k.p.k. wskazuje na wydanie polecenia przez sąd lub prokuratora, ale należy uznać, że jedyną prawidłową formą w tym wypadku jest postanowienie, a nie polecenie, o którym mowa w art. $93 \S 4$ k.p.k. ${ }^{31}$ Wynika to

25 Ibidem.

26 Problem ten poruszają między innymi G. Babieracki, Kontrola osobista. Jest problem, czy go nie ma, „Przegląd Prewencyjny” 2012, nr 5, s. 10-13; G. Babieracki, J. Konewko, S. Młynarski, op. cit.; G. Babieracki, Kontrola osobista, Słupsk 2010; D. Cyma-Końska, R. Wójcik, Kontrola osobista a przeszukanie, Legionowo 2015; D. Szumiło-Kulczycka, Kontrola osobista, przegladanie zawartości bagaży, przeszukanie. Przyczynek do kwestii racjonalności legislacji, „Państwo i Prawo" 2012, nr 3.

27 J. Karaźniewicz, op. cit., s. 286-287.

28 Ibidem.

29 Wyrok TK z dnia 14 grudnia 2017 roku, K 17/14, OTK-A 2018/4.

30 J. Karaźniewicz, op. cit., s. 281.

31 K. Kremens, [w:] System prawa karnego procesowego, t. 8. Dowody, cz. 3, red. J. Skorupka, Warszawa 2019, s. 3848. 
wprost z art. $220 \S 1$ k.p.k., który stanowi, iż zarządzenie przeszukania przybiera formę postanowienia. Warto zwrócić uwagę, że prokurator jako organ immanentnie związany z czynnościami postępowania przygotowawczego będzie dążył do zapewnienia efektywności tego postępowania, a to wiąże się z podejrzeniem, że jego decyzje w omawianym przedmiocie mogą nie być w pełni bezstronne i neutralne. Należałoby więc opowiedzieć się za przyznaniem owego uprawnienia sądowi, mając na uwadze, iż jest to organ niezawisły ${ }^{32}$. Inne systemy prawne przyjmują takie rozwiązanie ${ }^{33}$. K. Kremens w tym kontekście podnosi, że legitymacja organu uprawnionego do zarządzenia przeszukania jako środka przymusu wiąże się $\mathrm{z}$ ograniczeniem praw jednostki i decyzje $\mathrm{w}$ tym przedmiocie powinny przysługiwać sądowi (organowi niezawisłemu), dzięki czemu zapewniony zostałby pożądany poziom obiektywizmu i niezależności w ocenie zasadności przeprowadzenia czynności, czego nie może zapewnić prokurator ze względu na jego bliski związek z organami ścigania i prowadzonym postępowaniem przygotowawczym ${ }^{34}$. Za koniecznością przeprowadzenia zmian w tym zakresie opowiada się także A. Sakowicz, stwierdzając, że organom ścigania łatwo jest poświęcić prawo podmiotowe jednostki w imię sprawnego i efektywnego przeprowadzenia postępowania karnego ${ }^{35}$. Należy więc dążyć do zmian legislacyjnych w tym zakresie ze względu na konieczność zapewnienia jednostce odpowiedniego poziomu ochrony jej praw. Ponadto z punktu widzenia gwarancyjności odebranie prokuratorowi omawianego uprawnienia sprawi, że postanowienia o przeszukaniu wydane przez niezawisły organ pozwolą, dzięki obiektywnej ocenie okoliczności sprawy, na minimalizowanie zbędnych ingerencji w prywatnosśs ${ }^{36}$.

32 R.A. Stefański, [w:] Kodeks postępowania karnego. Komentarz, t. 2, red. R.A. Stefański, S. Zabłocki, Warszawa 2019, s. 718.

33 Takie rozwiązanie przyjmuje między innymi Konstytucja Stanów Zjednoczonych, która nakazuje, aby przeszukanie lub zatrzymanie było przeprowadzone na podstawie nakazu sądowego. Taki nakaz sądowy wydaje sędzia lub upoważniony urzędnik sądowy wskutek złożonego wniosku policjanta z wyraźnym wskazaniem na poszukiwany przedmiot (A. Opalska-Kasprzak, op. cit., s. 51). Z kolei w Szkocji nakaz przeszukania wydaje sędzia pokoju lub sędzia sądu karnego (por. wyrok TK z dnia 14 grudnia 2017 roku, K 17/14, OTK-A 2018/4, s. 33). Identycznie regulują to niemieckie przepisy, gdzie co do zasady o przeszukaniu decyduje sąd. Prokurator nie ma możliwości zarządzić przeszukania, ponieważ jako prowadzący postępowanie przygotowawcze obowiązany jest do uzyskania zgody sędziego na wszystkie czynności śledcze wiążące się z naruszeniem wolności osobistej oraz prywatności jednostki (K. Kremens, op. cit., s. 3806-3807).

34 K. Kremens, op. cit., s. 3850-3851.

35 A. Sakowicz, Przeszukanie mieszkania a prawa do poszanowania prywatności jednostki. Uwagi na marginesie przepisów Konstytucji RP oraz umów międzynarodowych, [w:] Teoretyczne i praktyczne problemy wspótczesnego prawa karnego: księga jubileuszowa dedykowana profesorowi Tadeuszowi Bojarskiemu, red. A. Michalska-Warias, I. Nowikowski, J. Piórkowska-Flieger, Lublin 2011, s. 915-916.

${ }^{36}$ K. Kremens, op. cit., s. 3853. 
Omawiając problematykę organu uprawnionego do zarządzenia przeszukania, nasuwa się problem związany z zarządzeniem przeszukania $\mathrm{w}$ sytuacjach niecierpiących zwłoki. $Z$ punktu widzenia jednostki istotne jest, w jaki sposób organ dokonuje oceny niedookreślonego zwrotu, jakim jest ,sytuacja niecierpiąca zwłoki”. W doktrynie wskazuje się, że określenie to należy wykładać zwężająco. Możemy zatem mówić o takiej sytuacji jedynie w wypadkach ekstraordynaryjnych, do czego zobowiązuje zasada proporcjonalności z art. 31 ust. 3 Konstytucji ${ }^{37}$. Gwarancją praw jednostki w omawianej sytuacji jest konieczność zatwierdzenia przeszukania przez sąd lub prokuratora. W tym wypadku mamy więc do czynienia z działaniem legalnym warunkowo, którego niezatwierdzenie powoduje, że działanie to nie wywołuje skutków procesowych ${ }^{38}$. Z uwagi na dolegliwość takiej czynności należy również postulować przekazanie uprawnienia do jej zatwierdzenia w gestię sądu, $\mathrm{z}$ takich samych względów jak wskazane, czyli w celu zapewnienia największego stopnia obiektywizmu ${ }^{39}$.

Oceniając przesłanki dotyczące przeszukania, należy zwrócić uwagę na nieskonkretyzowanie sposobu, w jaki oceniane jest, że dana rzecz może być uznana za dowód w sprawie. To bardzo ogólne sformułowanie ustawowe pozwala organom pozyskiwać jakiekolwiek dowody w sprawie. Nie jest bowiem sprecyzowane, że muszą to być dowody przestępstwa czy winy ${ }^{40}$. Możemy przez to rozumieć możliwość przeszukania dowolnych osób w dowolnej sprawie, także w celu dowiedzenia ich niewinności. Trzeba jednak pamiętać, że przeszukanie jest czynnością głęboko ingerującą w prawa człowieka, więc zasadne jest jej ograniczenie tylko do znalezienia rzeczy mających dla procesu niebagatelne znaczenie. Obecnie organy przeprowadzające przeszukanie same decydują, co jest rzeczą mogącą stanowić dowód w sprawie, a to od razu nasuwa wątpliwości co do tego, czy nie umożliwia to nadużycia uprawnień procesowych, na przykład nadmiernie ekstensywnego zakresu dokonywanej czynności albo niedookreślenia poszukiwanych przedmiotów. Widać więc jasno potrzebę ściślejszego uregulowania tej kwestii. Szczególnie istotne jest doprecyzowanie kryteriów, które pozwoliłyby ocenić, że dany przedmiot będzie uznany za dowód w sprawie.

Warto zwrócić uwagę, iż ustawodawca posługuje się określeniem ,uzasadniona podstawa do przypuszczenia, że wymienione rzeczy się tam znajdują". Uwzględniając domniemanie racjonalności ustawodawcy, należy przyjąć, że termin „przypuszczenie” nie jest tożsamy z terminem „podejrzenie”. „Przypuszczenie” to mniej niż ,podejrzenie” i podstawa do przeprowadzenia przeszukania nie wymaga tylu

37 A. Sakowicz, op. cit., s. 923.

38 Szerzej J. Skorupka, Czynności legalne warunkowo w postępowaniu karnym, „Prokuratura i Prawo" 2015, nr 1-2, s. 71.

39 A. Sakowicz, op. cit., s. 924.

40 J. Skorupka, Konstytucyjne i konwencyjne granice przeszukania w postępowaniu karnym (cz. 2), „Palestra” 2007, nr 11-12, s. 55. 
informacji, ilu potrzeba do wszczęcia procesu ${ }^{41}$. Jednakże w mojej ocenie nie mogą to być informacje błahe, na przykład domysł albo niepoparte niczym przypuszczenie, ponieważ musi istnieć podstawa na tyle mocna, aby móc wkroczyć w prawo jednostki do prywatności czy nietykalności osobistej. W literaturze uznaje się, że podstawą do przeprowadzenia przeszukania nie może być plotka, przypadkowo zdobyta informacja lub nawet informacja zdobyta podczas czynności operacyjno-rozpoznawczych (ze względu na jej niesformalizowany i pozaprocesowy charakter), ponieważ są to informacje niemożliwe do weryfikacji albo należące do tajnych czynności pozaprocesowych ${ }^{42}$. Jak słusznie wskazuje J. Skorupka, nie mogą być to okoliczności uzyskane w nieprocesowy sposób bądź informacje niezweryfikowanie, ponieważ z natury mają one wątpliwy charakter ${ }^{43}$. Nie należy jednak uzależniać możliwości dokonania przeszukania od posiadania stuprocentowej pewności, że w jego wyniku cel zostanie osiągnięty, jak zauważa bowiem H. Popławski, byłoby to absurdem. Jednocześnie zaznacza on, że decyzja taka powinna być podjęta z rozwagą oraz na podstawie takich danych, które w wysokim stopniu uprawdopodabniają przypuszczenie, że cel czynności zostanie osiągnięty ${ }^{44}$. Tak więc organ procesowy powinien za każdym razem ocenić, czy w konkretnej sytuacji przypuszczenie jest uzasadnione takimi danymi, które dają podstawę do przeprowadzenia przeszukania.

Organem uprawnionym do przeprowadzenia kontroli osobistej jest policjant podejmujący decyzję o konieczności dokonania tej czynności wskutek powzięcia uzasadnionego podejrzenia popełnienia czynu zabronionego pod groźbą kary. Fakt, że kontrola osobista nie ma procesowego charakteru, powoduje, że funkcjonariusz nie musi mieć pisemnego upoważnienia do przeprowadzenia czynności czy też nie jest on obligowany do uzyskania następczej zgody bądź zatwierdzenia dokonanej czynności $^{45}$. Brak kontroli nad zasadnością podjętych działań naraża jednostkę na nadużycia ze strony organów procesowych. W omawianym wypadku należy dążyć do zwiększenia ochrony jednostki poprzez ograniczenie arbitralnej ingerencji organów ścigania, gdyż możliwość złożenia zażalenia wydaje się niewystarczającą zaporą przed bezprawnie podejmowanymi działaniami ${ }^{46}$. Pożądanych zmian należałoby jednak upatrywać przede wszystkim w kontekście przesłanek warunkujących podjęcie omawianych czynności.

41 R. Koper, Przeszukanie w wypadkach niecierpiacych zwtoki, „Prokuratura i Prawo” 2014, nr 11-12, s. 19.

42 A. Kazanowski, Problematyka przeszukania mieszkania, „Prokuratura i Prawo” 2010, nr 4, s. 66 .

43 J. Skorupka, [w:] Kodeks postępowania karnego. Komentarz, red. J. Skorupka, Warszawa 2018, s. 514.

44 H. Popławski, Uwagi w sprawie zakresu rewizji domowej i osobistej, „Palestra” 1962, nr 7, s. 22.

45 A. Opalska-Kasprzak, op. cit., s. 73.

46 Wyrok TK z dnia 3 lipca 2018 roku, K 38/07, OTK-A 2008, nr 6, poz. 102. 
Odnosząc się do okoliczności warunkujących dopuszczalność przeprowadzenia kontroli osobistej, przede wszystkim należy zwrócić uwagę, że kontrola osobista dokonywana przez funkcjonariuszy ma nie do końca administracyjno-porządkowy charakter, a o wiele bardziej przypomina czynność procesową. Można dojść do takiego wniosku, badając kolejno przesłanki dokonania kontroli. Analizując ustawę o Policji, widzimy, że zawiera ona elementy charakterystyczne dla procesu karnego, a nawet uregulowania sprawiające wrażenie, jakoby to właśnie kontrola była instytucją uregulowaną z dużą większą dbałością o szczegóły, niż ma to miejsce w wypadku przeszukania. A przecież to regulacja czynności procesowej powinna być wzorem tworzenia instytucji do niej podobnych, zwłaszcza czynności pozaprocesowych. W tym wypadku tak nie jest. Wniosek taki uwidacznia się podczas analizy przesłanek dokonania kontroli osobistej. Ustawodawca zezwala na jej dokonanie w razie zaistnienia uzasadnionego podejrzenia popełnienia czynu zabronionego pod groźbą kary. Nie posługuje się więc w tym wypadku miernikiem przypuszczenia, a pozwala dokonać kontroli tylko w wyniku powzięcia stosownego podejrzenia. W związku z tym, czy nie należałoby na tym etapie przeprowadzić przeszukania albo wszcząć postępowanie karne, skoro okoliczności dające podstawę do jej przeprowadzenia są już dużo dalej idące niż tylko w wypadku przypuszczenia? Stanowi ono przecież podstawę do wszczęcia postępowania przygotowawczego z art. 303 k.p.k. Takie stanowisko zajmuje K. Eichstaedt ${ }^{47}$, który wskazuje, że należy w omawianym wypadku wszcząć postępowanie karne (postępowanie w niezbędnym zakresie) i wtedy dokonywać czynności procesowych. Ponadto słusznie autor ten podsumowuje, że kontrola osobista to w rzeczywistości przeszukanie dokonywane poza procesem karnym ${ }^{48}$. Należy w tym miejscu przywołać stanowisko D. Szumiło-Kulczyckiej, która dostrzega potrzebę podjęcia kontroli osobistej, gdy stopień prawdopodobieństwa popełnienia czynu nie jest jeszcze tak wysoki, aby uzasadnić wszczęcie postępowania lub na podjęcie kontroli osobistej będącej wynikiem jedynie działań zapobiegawczych ${ }^{49}$. Uważam to za zbyt daleko idące stanowisko, które pozwalałoby na nadmierną dozę elastyczności w stosowaniu tej instytucji. Oznaczałoby to, iż organ mógłby bez dostatecznych podstaw podjąć decyzję o przeprowadzeniu kontroli osobistej jedynie dla celów zapobiegawczych. Warto przywołać pogląd K. Dąbkiewicza odnośnie do kontroli osobistej skazanego, który stwierdza, że ,kontrola osobista musi być uzasadniona przez zaistnienie konkretnego zdarzenia lub okoliczności, słusznie zatem zwraca się uwagę, że nie może stanowić podstawy do prewencyjnej regularnej kontroli

47 K. Eichstaedt, Komentarz do art. 219, teza 4, [w:] Kodeks postępowania karnego, t. 1. Komentarz aktualizowany, red. D. Świecki, LEX/el. 2019, https://sip.lex.pl/\#/commentary/587748508/600127.

48 Ibidem.

49 D. Szumiło-Kulczycka, op. cit., s. 37. 
wszystkich skazanych ${ }^{50 "}$. Warto więc mieć na względzie ograniczenie kontroli osobistej tylko do uzasadnionych okolicznościami przypadków. Należy przy tym pamiętać, iż kontrola osobista może przybierać dość dolegliwe dla jednostki formy, od sprawdzenia zawartości odzieży po sprawdzenie miejsc intymnych. Postępowanie, w którym możemy dokonać głęboko ingerującego w intymność jednostki sprawdzenia jej ciała w celu zapewniania bezpieczeństwa obywatelom bez wyraźnych ku temu podstaw, mogłoby być odbierane jako brak zaufania do obywateli.

Poczynione spostrzeżenia uzasadniają konieczność takiego unormowania przesłanek instytucji przeszukania i kontroli osobistej, aby wyraźnie je od siebie oddzielić. Obecnie przesłanka w postaci „uzasadnionego podejrzenia popełnienia czynu zabronionego pod groźbą kary" mylnie nawiązuje do terminologii związanej z procesem karnym, a dokładnie z momentem wszczęcia procesu karnego. Taka regulacja przekłada się na błędne utożsamianie z sobą kontroli osobistej i przeszukania. Taki stan rzeczy wymaga korekty legislacyjnej, która pozwoliłaby wyraźnie oddzielić od siebie obie instytucje także z tego względu, że spełnienie przesłanek przeprowadzenia kontroli osobistej jest jednocześnie wypełnieniem przesłanek właściwych przeszukaniu ${ }^{51}$. Ponadto ustawodawca formułuje dodatkową przesłankę przeprowadzenia kontroli osobistej, którą jest znalezienie określonych w ustawie ogólnikowo przedmiotów, przez co sposobność dokonania kontroli osobistej jest $\mathrm{w}$ zasadzie niczym nieograniczona. To z kolei w pośredni sposób daje przyzwolenie na dowolną interpretację norm w tym zakresie i dokonywania kontroli osobistej bez wyraźnych ku temu podstaw. Dlatego należy wyznaczyć jasną linię demarkacyjną, tak sformułowawszy przesłanki kontroli osobistej, aby nie wiązały się z procesem karnym.

Istotnym rozwiązaniem zwiększającym poziom gwarancyjności kontroli osobistej jest wprowadzenie szczegółowej regulacji sposobu jej przeprowadzenia. Zakres czynności dokonywanych przez funkcjonariusza w związku z kontrolą osobistą jest bardzo szeroki i nie odbiega znacząco od właściwego przeszukaniu. Różnicą jest jedynie fakt, że podczas przeszukania zostaje sprawdzone całe ciało, a sposób jego dokonania jest determinowany przez praktykę, doktrynę prawniczą oraz taktykę kryminalistyczną. Regulacja dotycząca kontroli osobistej wskazuje zaś wyraźnie sposób jej dokonania, który może być wzrokowy, manualny, z wykorzystaniem psa służbowego lub środków technicznych. Następnie zawiera się w niej wyczerpujący opis czynności, do których jest zobligowany policjant. Chodzi o podanie stopnia, podstawy prawnej i przyczyny podjęcia kontroli osobistej. W ustawie zawarty jest też opis przebiegu odbioru od osoby kontrolowanej rzeczy stanowiących dowód. Nie ulega wątpliwości, że cała procedura została opisana dużo bardziej szczegółowo niż w wypadku przeszukania z k.p.k. Tę zmianę w od-

50 K. Dąbkiewicz, Komentarz do art. 116, teza 15, [w:] idem, Kodeks karny wykonawczy. Komentarz, Warszawa 2018.

51 J. Karaźniewicz, op. cit., s. 281. 
niesieniu do kontroli osobistej należy ocenić pozytywnie. Inaczej ma się ta kwestia w odniesieniu do przeszukania. Jak zauważa TK w wyroku o sygn. K 17/14 ${ }^{52}$ : „górny pułap przeszukania osoby [...] obejmować może, w ostateczności, daleko idącą ingerencję w nietykalność osobistą osoby przeszukiwanej, nie wyłączając poddania jej badaniom czy zaaplikowania emetyków". Zatem przeszukanie, jeśli chodzi o dokładne zbadanie ciała, jest w porównaniu do kontroli osobistej poważniejszą dolegliwością. Niezrozumiałe jest więc to, dlaczego ustawodawca postanowił w szeroki sposób uregulować kwestię dotyczącą przebiegu kontroli osobistej, a sposób przeprowadzenia przeszukania osoby pozostawił bez analogicznej regulacji, poprzestając wyłącznie na ogólnej dyrektywie umiaru. TK wielokrotnie podkreślał, że obowiązek uregulowania na poziomie ustawy ograniczeń konstytucyjnie chronionych praw i wolności to nie tylko kwestia wyłączności ustawowej, lecz przede wszystkim „nakaz kompletności uregulowania ustawowego, które musi samodzielnie określać wszystkie podstawowe elementy ograniczenia danego prawa i wolności, tak aby już na podstawie lektury przepisów ustawy można było wyznaczyć kompletny zarys (kontur) tego ograniczenia ${ }^{53}$ ". Taki stan rzeczy powoduje, że aktualna regulacja przeszukania osoby pozbawiona jest istotnego elementu gwarancyjności zapewniającego ochronę prywatności i nietykalności osobistej jednostki, ponieważ zakres i sposób przeprowadzenia przeszukania osoby nie jest wystarczająco doprecyzowany. W doktrynie można spotkać stanowisko, że regulacja przeszukania zawiera luki, które pozwalają na niekorzystną dla jednostki interpretację i dlatego instytucja ta powinna zostać bardzo szczegółowo unormowana, aby nie pozostawić organom nadmiernej swobody interpretacyjnej ${ }^{54}$. Podsumowując, omawiane unormowanie nie zabezpiecza należycie praw jednostki. Ponadto ustawodawca wykazuje się niekonsekwencją, regulując szczegółowo zakres czynności w wypadku kontroli osobistej, a nie uszczegółowia procedury w wypadku przeszukania, pozostawiając tym samym lukę. $\mathrm{Z}$ tych względów konieczna jest stosowna zmiana przepisów.

Odnosząc się do przebiegu przeszukania i kontroli osobistej, warto rozwinąć kwestię wprowadzonej przez ustawodawcę dyrektywy zachowania umiaru. W tym miejscu po raz kolejny widoczne są podobieństwa między kontrolą osobistą i przeszukaniem (art. 227 k.p.k. i art. 15d ust. 2 ustawy o Policji). Słuszne jest stwierdzenie J. Skorupki w odniesieniu do przeszukania, ale mającej odniesienie także dla kontroli osobistej, że wskazana dyrektywa ma charakter postulatywny i podkreśla pewien sposób postępowania, ale nie wytycza granic ingerencji organów postępowania karnego w konstytucyjnie zagwarantowane prawa i wolności ${ }^{55}$. Zawarcie tego typu normy gwarancyjnej w ustawie o Policji wydaje się niepotrzebnym za-

52 Wyrok TK z dnia 14 grudnia 2017 roku, K 17/14, OTK-A 2018/4.

53 Wyrok TK z 12 stycznia 2000 roku, sygn. P 11/98, OTK ZU 2000, nr 1, poz. 3.

54 K. Kremens, op. cit., s. 3776.

55 J. Skorupka, Konstytucyjne i konwencyjne granice..., s. 63. 
biegiem mającym na celu nawiązanie do art. 227 k.p.k. Tym bardziej że ustawodawca zaraz po wymienieniu czynności, których może dokonać Policja, wskazuje w art. 14 ust. 3 ustawy o Policji obowiązek respektowania przez nich godności ludzkiej oraz przestrzegania i ochrony praw człowieka. Natomiast w art. 15 ust. 6 ustawy o Policji precyzuje się, że czynności te powinny być dokonane w sposób jak najmniej naruszający dobra osobiste. Omawiane sformułowanie wydaje się zbędne także z uwagi na dość szczegółowy opis przebiegu kontroli osobistej zawarty w ustawie o Policji. Natomiast w wypadku regulacji kodeksowej konieczne jest ustanowienie norm nie tylko zawierających ogólne gwarancje (art. 227 k.p.k.), lecz także takich, które będą wskazywać wyraźne wytyczne dla organów procesowych. W literaturze można spotkać się z poglądem, wedle którego art. 227 k.p.k. nie formułuje żadnych konsekwencji w wypadku przekroczenia granic wyznaczonych przez tę normę $e^{56}$. Co więcej, naruszenie omawianego przepisu nie uchybia skuteczności czynności przeszukania ${ }^{57}$. Jednakże naruszenie wymagań art. 227 k.p.k. może być podstawą dochodzenia roszczeń przez poszkodowanego z tytułu naruszenia jego dóbr osobistych (art. 24 k.c.) lub z tytułu wyrządzenia mu szkody (art. 415-420 k.c.). Nieprzestrzeganie zasad przeprowadzania przeszukania może być także przedmiotem zarzutu podniesionego w zażaleniu (art. 236 k.p.k.) ${ }^{58}$.

Rozpatrując pozostałe kwestie dotyczące gwarancji procesowych, jakie przysługują jednostce w wypadku przeprowadzonego przeszukania, należy zauważyć, iż art. 143 k.p.k. nakłada obowiązek spisania protokołu po zakończonej czynności procesowej. Kodeks postępowania karnego wprowadza w art. 229 wymogi szczególne dotyczące treści protokołu przeszukania, co wskazuje na jego zwiększoną wobec innych czynności procesowych dolegliwość. Tymi szczególnymi wymogami jest między innymi oznaczenie sprawy, z którą przeszukanie ma związek, a także podanie dokładnej godziny rozpoczęcia i zakończenia przeszukania czy też wskazanie polecenia sądu lub prokuratora. Dla osoby poddanej przeszukaniu z pewnością istotne jest umieszczenie w protokole polecenia sądu bądź prokuratora, ponieważ, jak słusznie wskazuje A. Opalska-Kasprzak, konieczne jest wyraźne wskazanie w postanowieniu, jaka rzecz była poszukiwana, gdyż w innym wypadku może to oznaczać brak merytorycznych podstaw do zarządzenia przeszukania. Zauważa ona również, że nie wystarczy tu lakoniczny zwrot, iż chodzi o „znalezienie przedmiotów pochodzących z przestępstwa" ${ }^{59}$. Z pewnością obowiązek spisania takiego protokołu ma istotne znaczenie dla osoby poddanej przeszukaniu, ponieważ może on stanowić podstawę do dochodzenia przez nią naruszonych praw, jeśli na przykład przeszukanie zostało przeprowadzone z pominięciem zasad wskaza-

56 K. Kremens, op. cit., s. 3844.

57 J. Skorupka, [w:] Kodeks postępowania karnego. Komentarz, red. J. Skorupka, Warszawa 2018, s. 522.

58 Ibidem, s. 522.

59 A. Opalska-Kasprzak, op. cit., s. 278. 
nych przez ustawodawcę. Jest to więc istotny element gwarancyjny dla jednostki, gdyż jest podstawą oceny, czy ingerencja w jej prawa została dokonana zgodnie z celem przeszukania, z zachowaniem umiaru i poszanowania godności, a także czy jej przeprowadzenie nie wyrządziło niepotrzebnych szkód i dolegliwości.

Analogicznie do przeszukania postanowiono uregulować kwestię sporządzania protokołu z kontroli osobistej. Istnienie możliwości sporządzenia protokołu należy ocenić pozytywnie, gdyż przed 9 października 2015 roku wystarczające było jedynie odnotowanie faktu kontroli osobistej w notatniku służbowym. Aktualnie po zakończonej kontroli osobistej sporządzany jest protokól: fakultatywnie, jeśli osoba kontrolowana bezpośrednio po przeprowadzonej czynności tego zażąda, oraz obowiązkowo, gdy organ w toku kontroli znajdzie broń lub inne przedmioty stanowiące dowód. Jak wiadomo, spisanie protokołu jest charakterystyczne dla większości czynności procesowych. $\mathrm{W}$ omawianym wypadku mamy do czynienia ze spisaniem protokołu, ale tylko w przypadku zgłoszonego żądania. W pozostałych wypadkach kontrolę dokumentuje się w dokumentacji służbowej, co jest przejawem odformalizowania tej instytucji. Dla odmiany w kodeksie postępowania karnego organ nie ma w żadnym przypadku możliwości zrezygnowania ze sporządzenia protokołu ${ }^{60}$. Pozostaje jedynie wątpliwość co do tego, czy funkcjonariusz, który nie jest zmuszony do sporządzenia protokołu, zawsze pouczy stronę o możliwości zgłoszenia żądania sporządzenia takiego protokołu. Oczywiście przyjęcie w wypadku kontroli osobistej rygoru spisania protokołu na żądanie należy ocenić pozytywnie, gdyż z racji ingerencji w sferę intymności człowieka stanowi to gwarancję ochrony jego praw, a dodatkowo pozwala odstąpić od czasochłonnego sporządzania protokołu, w wypadku gdy nie było takiej konieczności ${ }^{61}$.

$\mathrm{Na}$ uwagę zasługuje problematyka prawa do sądu w przypadku przeszukania i kontroli osobistej. Gdy mowa o przeszukaniu, narzędziem ochrony pozwalającym jednostce zbadać legalność i prawidłowość tej czynności jest możliwość zaskarżenia w drodze zażalenia wszelkich postanowień dotyczących przeszukania. $\mathrm{W}$ postępowaniu przygotowawczym organem odwoławczym jest sąd rejonowy, a gdy postanowienie w przedmiocie przeszukania zostało wydane $\mathrm{w}$ toku postępowania jurysdykcyjnego, zażalenie rozpoznaje sąd nadrzędny nad wydającym postanowienie. Natomiast od postanowień i zarządzeń wydanych przez referendarza sądowego przysługuje sprzeciw. Wniesienie sprzeciwu powoduje utratę mocy postanowienia lub zarządzenia z mocy samego prawa. W wypadku kontroli osobistej unormowanie tej kwestii zostało zmienione przez ustawodawcę wsku-

${ }^{60} \mathrm{~K}$. Eichstaedt wskazuje, że organ może odstąpić od niezwłocznego sporządzenia protokołu na przykład w sytuacji ujęcia sprawcy przestępstwa w pościgu, gdy trzeba go przeszukać w celu odebrania broni. Ma to zapewnić rzetelność sporządzonego protokołu poprzez oddanie rzeczywistego przebiegu czynności. (K. Eichstaedt, Komentarz do art. 229 k.p.k., teza 3, [w:] Kodeks postępowania karnego, t. 1. Komentarz aktualizowany...

61 D. Szumiło-Kulczycka, op. cit., s. 44. 
tek orzeczenia Trybunału Konstytucyjnego ${ }^{62}$. Osobie kontrolowanej przysługuje zażalenie do sądu rejonowego właściwego ze względu na miejsce dokonania kontroli osobistej w terminie 7 dni od dnia dokonania czynności. Postępowanie zażaleniowe ma na celu zbadanie przez sąd zasadności, legalności oraz prawidłowości jej dokonania. Jeśli sąd stwierdzi, że zachodzi uchybienie, zawiadamia o tym prokuratora i kierownika jednostki organizacyjnej Policji nadrzędnej nad jednostką, w której służbę pełnił policjant przeprowadzający kontrolę. Z aprobatą należy ocenić dokonaną zmianę zapewniającą osobie kontrolowanej możliwość dochodzenia ochrony swoich praw i wolności. Gdy mowa o czynnościach wiążących się z zastosowaniem środka przymusu, prawo do sądu powinno być standardem wynikającym z art. 77 ust. 2 Konstytucji, gdyż jest to podstawowy środek ochrony praw i wolności jednostki ${ }^{63}$. Przechodząc dalej, nie sposób pominąć faktu, że w art. 15 ust. 1 pkt 4 ustawy o Policji ustawodawca przyznaje Policji prawo do przeszukiwania osób w trybie i przypadkach określonych w przepisach k.p.k. W związku z tym uprawnieniem istnieje możliwość złożenia zażalenia na tę czynność do miejscowo właściwego prokuratora na podstawie art. 15 ust. 7 ustawy o Policji. Oznacza to, że oprócz przewidzianego w k.p.k. zażalenia do sądu rejonowego ustawa o Policji przyznaje dodatkową możliwość złożenia zażalenia na sposób przeprowadzenia przeszukania do prokuratora. Zakres przedmiotowy obu zażaleń się pokrywa. Zażalenie, o którym mowa w art. 236 k.p.k., przysługuje bowiem także na czynności faktyczne, między innymi na samo przeprowadzenie przeszukania ${ }^{64}$. Takie rozwiązanie wydaje się zbędne, gdyż trudno przyjąć, aby prokurator, który prowadzi albo nadzoruje postępowanie przygotowawcze i jest zainteresowany jego wynikami, był organem gwarantującym całkowitą bezstronność w toku rozpoznawania sprawy ${ }^{65}$.

Gwarancyjność regulacji dotycząca przeszukania osoby i kontroli osobistej jest zachwiana przez mnożenie instytucji do nich podobnych. Omówione wcześniej sprawdzenie prewencyjne jest kolejną instytucją mającą zapewnić służbom dodatkowe uprawnia, które w podobnym stopniu ingerują w prywatność jednostki, a poza nazewnictwem niewiele je różni. Co więcej, jak wynika z analizy przepisów ustawy o Policji, sprawdzenie prewencyjne często traktuje się jako kontrolę osobistą, na przykład po spełnieniu przesłanki ujawnienia broni (art. $15 \mathrm{~g}$ ust. 6 ustawy o Policji), a gdy zaistnieją przesłanki z art. 15 ust. 1 pkt 5 ustawy o Policji, sprawdzenie prewencyjne zastępuje się kontrolą osobistą. Dodatkowo nakazuje się Policji, aby w trakcie przeprowadzania sprawdzenia prewencyjnego kierować się

${ }^{62}$ Wyrok TK z dnia 14 grudnia 2017 roku, K 17/14, OTK-A 2018, nr 4.

63 L. Garlicki, Polskie prawo konstytucyjne. Zarys wykładu, Warszawa 2015, s. 118.

${ }^{64}$ K. Eichstaedt, Komentarz do art. 236, teza 1, [w:] Kodeks postepowania karnego, t. 1. Komentarz aktualizowany...

65 S. Steinborn, Problem organu uprawnionego do stosowania przeszukania $w$ toku procesu karnego w świetle unormowań konstytucyjnych i międzynarodowych, „Gdańskie Studia Prawnicze" 19, 2008, s. 374. 
zasadami właściwymi kontroli osobistej (art. 15g ust. 5 ustawy o Policji). W takim wypadku należy postawić pytanie, czy novum, jakim jest sprawdzenie prewencyjne, jest instytucją niezbędną Policji, czy też wyodrębnienie tej czynności jest podyktowane chęcią obejścia rygorów znanych kontroli osobistej? Wprowadzenie instytucji sprawdzenia prewencyjnego daje bowiem służbom przyzwolenie na stosowanie tego środka jako dla nich korzystniejszego (brak ściśle określonych zasad i sytuacji jego stosowania), a także ze względu na brak kontroli prawidłowości podjętej czynności. Mając na względzie poczynione uwagi, należy zauważyć, że regulacja sprawdzenia prewencyjnego nie jest wystarczająco dookreślona, jeśli chodzi o przesłanki jej przeprowadzenia. Jak wskazano, ustawodawca, wprowadzając ogólne sformułowanie „w celu ochrony”, daje funkcjonariuszom Policji nadmierną swobodę przy ustalaniu, czy dana sytuacja kwalifikuje się do przeprowadzenia tej czynności. Takie uregulowanie może zostać uznane za naruszenie art. 2 Konstytucji, gdyż artykuł ten nakazuje formułować przepisy jasno i precyzyjnie, aby uniknąć nadmiernej swobody przy ustalaniu zakresu podmiotowego i przedmiotowego ograniczeń praw i wolności jednostki ${ }^{66}$. Regulacja sprawdzenia prewencyjnego nie jest więc wystarczająco precyzyjnie określona, co naraża jednostkę na nadużycia ze strony organów Policji.

Nie ma wątpliwości, że potrzebne jest Policji uprawnienie, które pozwala zapobiegać działaniom przestępczym i zapewnia obywatelom bezpieczeństwo, a przy okazji nie jest nacechowane nadmiernym formalizmem, który mógłby negatywnie wpływać na efektywność działania tego organu. Jednakże przesłanki jego przeprowadzenia powinny być klarowne i nie pozostawiać wątpliwości co do celu, dla którego zostały stworzone. Ponadto przez nieprecyzyjność przesłanek i zakresu stosowania tej instytucji trudno wyznaczyć jasne granice stosowania sprawdzenia prewencyjnego. To może wskazywać na niespełnienie wymaganego przez Konstytucję testu proporcjonalności danej normy. Wątpliwa jest zatem konieczność istnienia takiej regulacji z uwagi na fakt, że ze względu na jej dolegliwą formę mamy do czynienia ze swego rodzaju kontrolą osobistą. Tymczasem nie powinno to być uprawnienie możliwe do stosowania zamiennego $\mathrm{z}$ kontrolą osobistą tylko dlatego, że przepisy na to pozwalają i dublują katalog działań prewencyjnych.

Niepokoi i zasługuje na krytykę brak jakiejkolwiek ochrony prawnej jednostki w wypadku dokonanego sprawdzenia prewencyjnego. Ustawodawca nie przewidział tutaj ani zażalenia do miejscowo właściwego prokuratora na sposób przeprowadzenia czynności sprawdzenia, ani możliwości spisania protokołu, chociażby na żądanie osoby poddanej sprawdzeniu prewencyjnemu. Co ciekawe, na wszystkie inne uprawnienia Policji, z wyjątkiem prawa do przeprowadzenia kontroli osobistej i owego sprawdzenia prewencyjnego, takie zażalenie do prokuratora przysługuje. O ile w wypadku kontroli osobistej pozbawienie takiego uprawnienia wynika z możliwości złożenia zażalenia do sądu rejonowego, o tyle z niewiadomych

66 Por. np. wyrok TK z 12 grudnia 2005 roku, K 32/04, OTK-A 2005, nr 11, poz. 132. 
przyczyn sprawdzenie prewencyjne zostało pozbawione jakichkolwiek gwarancji chroniących jednostkę. Taka regulacja jest niedopuszczalna w świetle art. 45 ust. 1 i art. 77 ust. 2 Konstytucji. Prawo do sądu jest podstawową gwarancją jednostki, której prawa i wolności zostały naruszone. Analizując regulacje dotyczące sprawdzenia prewencyjnego, widoczne jest ograniczenie wolności jednostki, stąd niezrozumiałe jest nieuregulowanie przez ustawodawcę tej kwestii. Stanowisko TK (odnośnie do zarządzenia kontroli przez funkcjonariuszy BOR, SKW, SWW bez jakiejkolwiek kontroli pochodzącej z zewnątrz) nie pozostawia wątpliwości co do tego, że brak jakiegokolwiek mechanizmu zewnętrznej kontroli przeprowadzonego sprawdzenia prewencyjnego narusza normy konstytucyjne. Jak wskazuje bowiem w sprawie K 17/14

taka regulacja prawna, choć niewątpliwie odpowiadająca potrzebom praktyki, przeczy standardom państwa prawnego, które musi gwarantować weryfikację czynności stanowiących ingerencję w sferę dóbr osobistych człowieka. Mamy w tym wypadku do czynienia z, podlegającym kognicji TK, pominięciem prawodawczym, polegającym na nieustanowieniu odpowiednich mechanizmów kontroli wykonywania uprawnień funkcjonariuszy wskazanych służb ${ }^{67}$.

Zatem ustanowienie możliwości weryfikacji legalności, zasadności i prawidłowości w wypadku sprawdzenia prewencyjnego jest zabiegiem koniecznym zarówno z punktu widzenia spójności regulacji (na sprawdzenie prewencyjne jako jedyne spośród uprawnień policyjnych nie przysługuje zażalenie do prokuratora), jak i ze względu na zapewnienie wymaganego prawem poziomu gwarancyjności.

Mając na względzie uwagi dotyczące sprawdzenia prewencyjnego, należy stwierdzić, że Policja ma wiele pozaprocesowych uprawnień ingerujących w prywatność i nietykalność osobistą obywateli. Należy zastanowić się nad uregulowaniem tych kompetencji w taki sposób, aby jak najmniej ingerowały w prawa jednostki, a mimo to zapewniały możliwość skutecznej ochrony bezpieczeństwa i porząaku publicznego. Oczywiście nie chodzi tu o likwidację ustawowo przyznanych Policji kompetencji, ponieważ mogłoby to prowadzić do sytuacji, w której organy pozbawione są możliwości działania. Możliwym rozwiązaniem wydaje się inkorporowanie stosownych regulacji do instytucji kontroli osobistej, ponieważ obecnie omawiane czynności znacząco od siebie nie odbiegają. Istotne jest, aby regulacja ustawowa nie kreowała zbędnie instytucji mających podobny cel i charakter.

Podsumowując, należy stwierdzić, że analiza aspektów materialnych i proceduralnych przeszukania i kontroli osobistej prowadzi do wniosku, że kontrola osobista czerpie z przeszukania na tyle mocno, że staje się ona niemalże kopią tej czynności procesowej. Są to dwie instytucje oparte na przymusie, które służą temu samemu celowi i mają w bardzo zbliżony sposób uregulowane przesłanki determinujące możliwość ich podjęcia. Właściwie tym, co je odróżnia, jest ich charakter. W wypadku kontroli osobistej jest to administracyjno-porządkowy cha-

67 Wyrok TK z dnia 14 grudnia 2017 roku, K 17/14, OTK-A 2018, nr 4. 
rakter, którego istota sprowadza się do zapewnienia bezpieczeństwa i porządku publicznego. Przeszukanie z kolei to czynność procesowa mająca niebagatelne znaczenie dla pozyskania dowodów w postępowaniu karnym. Zarówno kontrola osobista, jak i przeszukanie wkraczają w materię praw i wolności określonych w art. 41 ust. 1 i art. 47 Konstytucji. Unormowanie w podobny sposób de facto tych samych czynności stanowi przyzwolenie na wybór między korzystniejszą w danym wypadku formą działania, co skutkuje brakiem dostatecznych gwarancji dla jednostki. Aby tego uniknąć, konieczne wydaje się przeformułowanie przesłanek tych instytucji. Należy więc postulować określenie przesłanek kontroli osobistej, tak aby nie były one powiązane z procesem karnym, chociażby poprzez odniesienie do zapewnienia bezpieczeństwa i porządku publicznego, gdy wiąże się to z zachowaniami przestępczymi czy też sytuacjami zwiększonego ryzyka. Należy również postulować zmiany w zakresie określenia sposobu przeprowadzenia przeszukania, na wzór kontroli osobistej. Niewystarczające jest bowiem istnienie norm zawierających ogólne gwarancje jak w wypadku art. 227 k.p.k. Ponadto, oceniając gwarancyjność instytucji przeszukania, uwidacznia się konieczność zmian w zakresie właściwości organu, który podejmuje decyzję o dokonaniu przeszukania, a także zatwierdzającego przeszukanie podjęte w sytuacjach niecierpiących zwłoki. W świetle obowiązującego prawa konieczne jest przekazanie tego uprawnienia organowi niezawisłemu, ponieważ ze względu na wysoką wrażliwość tej czynności tylko taka regulacja zmaksymalizuje szansę, aby decyzję o przeszukaniu podjęto w pełni obiektywnie. Na krytykę zasługuje również wprowadzenie przez ustawodawcę podobnej do kontroli osobistej instytucji sprawdzenia prewencyjnego. Powoduje to, że ochrona prywatności i nietykalności osobistej jednostki jest zagrożona przez powielanie instytucji, które dają zezwolenie na wybór między korzystniejszą z nich. W związku z tym instytucja sprawdzenia prewencyjnego powinna zostać zlikwidowana. Regulacja ta bowiem nie zapewnia odpowiedniego poziomu poszanowania praw podmiotowych jednostki. Kontrola osobista po odpowiednim przeformułowaniu przesłanek mogłaby spełniać cele przewidziane dla sprawdzenia prewencyjnego. Zapewnienie spójności oraz odpowiednich gwarancji w wypadku instytucji opierających się na przymusie ma bowiem niebagatelne znaczenie z punktu widzenia efektywnej ochrony praw jednostki.

\section{Bibliografia}

Babieracki G., Kontrola osobista, Słupsk 2010.

Babieracki G., Kontrola osobista. Jest problem, czy go nie ma, „Przegląd Prewencyjny” 2012, nr 5.

Babieracki G., Konewko J., Młynarski S., Sprawdzenie osoby, kontrola osobista a przeszukanie w codziennej stużbie Policjanta, Słupsk 2011.

Cieślak M., Zagadnienia dowodowe w procesie karnym, Warszawa 1955.

Cyma-Końska D., Wójcik R., Kontrola osobista a przeszukanie, Legionowo 2015.

Dąbkiewicz K., Komentarz do art. 235, [w:] idem, Kodeks postępowania karnego. Komentarz do zmian 2015, LEX, https://sip.lex.pl/\#/commentary/587682787/480227. 
Dąbkiewicz K., Komentarz do art. 116, teza 15, [w:] idem, Kodeks karny wykonawczy. Komentarz, wyd. 4, Warszawa 2018.

Eichstaedt K., Komentarz do art. 219, teza 4, [w:] Kodeks postępowania karnego, t. 1. Komentarz aktualizowany, red. D. Świecki, LEX/el. 2019, https://sip.lex.pl/\#/commentary/587748508/600127.

Eichstaedt K., Komentarz do art. 236, teza 1, [w:] Kodeks postepowania karnego, t. 1. Komentarz aktualizowany, red. D. Świecki, LEX/el. 2019, https://sip.lex.pl/\#/commentary/587748525/600145.

Eichstaedt K., Komentarz do art. 229 k.p.k., teza 3, [w:] Kodeks postępowania karnego, t. 1. Komentarz aktualizowany, red. D. Świecki, LEX/el. 2019, https://sip.lex.pl/\#/commentary $/ 587748517 / 600137$.

Garlicki L., Polskie prawo konstytucyjne. Zarys wyktadu, Warszawa 2015.

Grzegorczyk T., Kodeks postepowania karnego. Komentarz do art. 1-467, t. 1, Warszawa 2014.

Grzeszczyk W., Komentarz do art. 219, teza 1-2, [w:] Kodeks postępowania karnego. Komentarz, LexisNexis 2012, LEX, https://sip.lex.pl/\#/commentary/587620891/278234.

Hochberg L., Murzynowski A., Schaff L., Komentarz do kodeksu postepowania karnego, Warszawa 1959.

Karaźniewicz J., Przeszukanie i czynności zbliżone do przeszukania w teorii i praktyce organów ścigania, [w:] Węzłowe problemy procesu karnego, red. P. Hofmański, Warszawa 2010.

Koper R., Przeszukanie w wypadkach niecierpiacych zwłoki, „Prokuratura i Prawo” 2014, nr 11-12.

Kozanowski A., Problematyka przeszukania mieszkania, „Państwo i Prawo” 2010, nr 4.

Kremens K., [w:] System prawa karnego procesowego. Dowody, t. 8, cz. 3, red. J. Skorupka, Warszawa 2019.

Kurowski M., Komentarz do art. 93 a k.p.k., teza 1, [w:] Kodeks postępowania karnego. Komentarz, t. 1, wyd. 4, red. D. Świecki, Warszawa 2018.

Opalska-Kasprzak A., Przeszukanie. Problematyka prawna i kryminalistyczna, Warszawa 2018.

Popławski H., Uwagi w sprawie zakresu rewizji domowej i osobistej, „Palestra” 1962, nr 7.

Sakowicz A., Przeszukanie mieszkania a prawa do poszanowania prywatności jednostki. Uwagi na marginesie przepisów Konstytucji RP oraz umów międzynarodowych, [w:] Teoretyczne i praktyczne problemy wspótczesnego prawa karnego: księga jubileuszowa dedykowana profesorowi Tadeuszowi Bojarskiemu, red. A. Michalska-Warias, I. Nowikowski, J. Piórkowska-Flieger, Lublin 2011.

Skorupka J., [w:] Kodeks postępowania karnego. Komentarz, red. J. Skorupka, Warszawa 2018.

Skorupka J., [w:] System Prawa Karnego Procesowego, t. 1. Zagadnienia ogólne, cz.1, red. P. Hofmański, Warszawa 2013.

Skorupka J., Czynności legalne warunkowo w postępowaniu karnym, „Państwo i Prawo” 2015, nr $1-2$.

Skorupka J., Konstytucyjne i konwencyjne granice przeszukania w postępowaniu karnym (cz. 2), „Palestra" 2007, nr 11-12.

Stefański R.A., [w:] Kodeks postępowania karnego. Komentarz, t. 2, red. R.A. Stefański, S. Zabłocki, Warszawa 2019.

Steinborn S., Problem organu uprawnionego do stosowania przeszukania w toku procesu karnego $w$ świetle unormowań konstytucyjnych i międzynarodowych, „Gdańskie Studia Prawnicze” 19, 2008.

Szumiło-Kulczycka D., Kontrola osobista, przegladanie zawartości bagaży, przeszukanie. Przyczynek do kwestii racjonalności legislacji, „Państwo i Prawo” 2012, nr 3.

Uniszewski Z., Przeszukanie problematyka kryminalistyczna, Warszawa 2000.

Waltoś S., Hofmański P., Proces karny. Zarys systemu, Warszawa 2018.

Studenckie Prace Prawnicze, Administratywistyczne

i Ekonomiczne 30, 2019

(C) for this edition by CNS 


\section{Orzecznictwo}

Wyrok TK z dnia 12 stycznia 2000 roku, sygn. P 11/98, OTK ZU 2000, nr 1, poz. 3.

Wyrok TK z dnia 12 grudnia 2005 roku, K 32/04, OTK-A 2005, nr 11, poz. 132.

Wyrok TK z dnia 14 grudnia 2017 roku, K 17/14, OTK-A 2018, nr 4.

Wyrok TK z dnia 3 lipca 2018 roku, K 38/07, OTK-A 2008, nr 6, poz. 102.

\section{Akty prawne}

Konstytucja Rzeczypospolitej Polskiej z dnia 2 kwietnia 1997 roku (Dz.U. Nr 78, poz. 483 z późn. $\mathrm{zm}$.).

Ustawa z dnia 6 kwietnia 1990 roku o Policji (tekst jedn. Dz.U. z 2019 r. poz. 161 z późn. zm.).

Ustawa z dnia 12 października 1990 roku o Straży Granicznej (tekst jedn. Dz.U. z 2019 r. poz. 147 z późn. zm.).

Ustawa z dnia 6 czerwca 1997 roku Kodeks postępowania karnego (tekst jedn. Dz.U. z 2018 r. poz. 1987 z późn. zm.).

Ustawa z dnia 24 maja 2002 roku o Agencji Bezpieczeństwa Wewnętrznego oraz Agencji Wywiadu (tekst jedn. Dz.U. z 2018 r. poz. 2387 z późn. zm.).

Ustawa z dnia 9 czerwca 2006 roku o Centralnym Biurze Antykorupcyjnym (tekst jedn. Dz.U. z 2019 r. poz. 1921). 